Kredo 4 (2020)
KREDO: Jurnal Ilmiah Bahasa dan Sastra
Terakreditasi Sinta 4 berdasarkan Keputusan Direktorat
Jenderal Penguatan Riset dan Pengembangan,
Kementerian Riset, Teknologi dan Pendidikan Tinggi
Republik Indonesia
Nomor: 23/E/KPT/2019. 08 Agustus 2019
https://jurnal.umk.ac.id/index.php/kredo/index

\title{
FAKTOR PENYEBAB KESULITAN MENULIS FABEL DAN MODEL PEMBELAJARAN YANG DIHARAPKAN MAHASISWA PENDIDIKAN BAHASA DAN SASTRA INDONESIA UNIVERSITAS SANATA DHARMA
}

\author{
Fransisca Despa Listiani \\ fransisca.despa@gmail.com
}

Universitas Sanata Dharma, Yogyakarta

Info Artikel
Sejarah Artikel
Diterima
19 Juni 2020
Disetujui
23 Juni 2020
Dipublikasikan
28 Oktober 2020
Keywords
difficulty factor
writing fable
learning model
Kata Kunci
faktor kesulitan
menulis fabel
model pembelajaran

Info Artikel :

This article aims to describe the factors that cause student difficulties in PBSI USD in learning to write fable and to describe the model of writing fable expected by students. This research is a qualitative descriptive study. The data source of this study is the students of PBSI USD who joined in the course of creative writing skills amounting to 17 people. Data collection is done by questionnaire technique. The results of the study were delivered as follows. Internal factors that lead students to natural difficulties writing fable include: 1) lack of interest and motivation, 2) difficulty in finding an insirpiration, 3) lack of in-depth knowledge of the concept of fable, and 4) lack of skills in writing-speaking such as diction, coherency, language style, and mastery of PUEBI. The external factors that cause students difficulties in nature writing fable include: 1) the presence of impaired concentration, 2) lack of time in the workmanship, and 3) which causes students difficulty in nature writing fable include: 1) difficulties in the publication of works. In general, the most dominant difficulties experienced by students is the difficulty to get the idea/topic is experienced by 16 students from a total of 17 respondents with a percentage of $12 \%$. As for, the most dominant learning model expected by students is a learning model that contains survey activities to the field or the environment to obtain information and a real description of the animals and the human basic traits to be made fable. The Model was expected by 7 students from a total of 17 respondents with a percentage of $28 \%$.

\section{Abstrak}

Tulisan ini bertujuan untuk untuk mendeskripsikan faktor penyebab kesulitan mahasiswa PBSI USD dalam pembelajaran menulis fabel dan mendeskripsikan model pembelajaran menulis fabel yang diharapkan oleh mahasiswa. Penelitian ini merupakan penelitian deskriptif kualitatif. Sumber data dari penelitian ini adalah mahasiswa PBSI USD yang tergabung dalam mata kuliah Keterampilan menulis kreatif berjumlah 17 orang. Pengumpulan data dilakukan dengan teknik kuesioner. Hasil penelitian disampaikan sebagai berikut. Faktor internal yang menyebabkan mahasiswa kesulitan alam menulis fabel meliputi: 1) kurangnya minat dan motivasi, 2) kesulitan mencari insirpirasi, 3) kurangnya pengetahuan yang mendalam tentang konsep fabel, dan 4) kurangnya keterampilan dalam berbahasa tulis seperti diksi, koherensi, gaya bahasa, dan penguasaan PUEBI. Faktor ekternal yang menyebabkan mahasiswa kesulitan alam menulis fabel meliputi: 1) adanya gangguan konsentrasi, 2) kurangnya waktu dalam pengerjaan, dan 3) yang menyebabkan mahasiswa kesulitan alam menulis fabel meliputi: 1) kesulitan dalam publikasi karya. Secara umum, kesulitan yang paling dominan dialami oleh mahasiswa adalah kesulitan untuk mendapatkan ide/topik yaitu dialami oleh 16 mahasiswa dari total 17 responden dengan persentase sebesar $12 \%$. Adapun, model pembelajaran yang paling dominan diharapkan oleh mahasiswa adalah model pembelajaran yang memuat kegiatan survei ke lapangan atau lingkungan hidup untuk memperoleh informasi dan gambaran nyata tentang hewan dan sifat-sifat dasar manusia untuk dibuat fabel. Model tersebut diharapkan oleh 7 mahasiswa dari total 17 responden dengan persentase sebesar $28 \%$.

\section{PENDAHULUAN}

Keterampilan menulis kreatif adalah salah satu keterampilan berbahasa yang penting untuk dikuasai oleh mahasiswa.
Kreativitas diperlukan untuk menghadapi tantangan abad 21. Kesuksesan individu akan didapatkan oleh mahasiswa yang memiliki keterampilan kreatif (Zubaidah 2017).

112 | Jurnal Kredo Vol. 4 No. 1 Oktober 2020 


Kredo 4 (2020)
KREDO: Jurnal Ilmiah Bahasa dan Sastra
Terakreditasi Sinta 4 berdasarkan Keputusan Direktorat
Jenderal Penguatan Riset dan Pengembangan,
Kementerian Riset, Teknologi dan Pendidikan Tinggi
Republik Indonesia
Nomor: 23/E/KPT/2019. 08 Agustus 2019
https://jurnal.umk.ac.id/index.php/kredo/index

Salah satu proses kreatif adalah keterampilan menulis kreatif. Dengan pembelajaran menulis kreatif, mahasiswa dapat mengembangkan keterampilan menulisnya sehingga menjadi pribadi yang lebih kreatif. Hal itu sejalan dengan pendapat Arsanti (2018) bahwa mahasiswa diharapkan mempunyai keterampilan menulis kreatif dengan baik sebagai salah satu kecakapan hidup (life skill).

Penguasaan keterampilan menulis merupakan suatu hal yang perlu menjadi perhatian kita semua (Yusuf 2013). Kreativitas seseorang dapat terlihat dari keterampilannya dalam menulis karya sastra salah satunya fabel. Salah satu bentuk praktek dan latihan untuk memperoleh penguasaan menulis, sebagai salah satu dari empat keterampilan berbahasa dilakukan melalui kegiatan pembelajaran (Tarigan, \& Henry 1994).

Keberhasilan dalam proses pembelajaran dipengaruhi oleh beragam faktor. Minat belajar mahasiswa merupakan salah satu faktor yang sangat penting atau dominan dalam keberhasilan pendidikan khususnya pembelajaran di kelas (Darmuki, Hariyadi 2020). Hal itu merupakan salah satu faktor yang berasal dari dalam diri mahasiswa. Sementara, faktor-faktor yang berasal dari luar mahasiswa seperti kemampuan dosen dalam merancang berbagai elemen pembelajaran juga perlu diperhatikan demi menunjang keberhasilan berlajar mahasiswa. Oleh sebab itu, upaya menganalisis kesulitan dan mengetahui harapan mahasiswa terkait pembelajaran yang ideal perlu dilakukan sebagai bentuk evaluasi dan refleksi untuk menyiapkan pembelajaran berikutnya.

Dalam kegiatan perkuliahan di PBSI USD, keterampilan menulis mahasiswa dapat digali dengan mengikuti mata kuliah Keterampilan Menulis Kreatif (KMK). Adapun, Standar Kompetensi (SK), Kompetensi Dasar (KD), dan materi yang dipelajari terdapat dalam silabus mata kuliah KMK yang disusun oleh dosen pengampu. Adapun SK, KD, dan materi pembelajaran menulis fabel dalam mata kuliah KMK diuraikan sebagai berikut.

Tabel 1. SK, KD, dan Materi Pokok Pembelajaran Menulis Fabel

\begin{tabular}{llrl}
\hline $\begin{array}{l}\text { Standar } \\
\text { Kompetensi }\end{array}$ & Kompetensi & Dasar & $\begin{array}{l}\text { Materi } \\
\text { Pokok }\end{array}$ \\
\hline Mahasiswa memiliki & Mampu menulis & Praktik \\
pengetahuan tentang & kreatif dan & menulis \\
menulis kreatif, & mempresentasikan & kreatif \\
memiliki & hasil tulisannya & subtema \\
keterampilan & dihadapan orang lain & cerita fiksi; \\
menulis kreatif, dan & & & cerita \\
memiliki sikap & & binatang \\
positif terhadap & & (fabel). \\
menulis kreatif & & & \\
\hline
\end{tabular}

Informasi tersebut menjadi acuan dosen pengampu dalam menuntun arah pembelajaran menulis fabel di mata kuliah Keterampilan Menulis Kreatif selama ini.

Keterampilan menulis menjadi salah satu keterampilan yang dianggap sulit dipelajari oleh mahasiswa. Pernyataan tersebut didukung oleh hasil penelitian Alwasilah (2002) bahwa berdasarkan persepsi para responden, sistem pendidikan nasional sejak SD sampai PT membekali keterampilan menulis (23.34\%), keterampilan membaca $(23.45 \%)$, dan keterampilan berpikir kritis $(31.86 \%)$. Selain itu, mayoritas responden (lebih dari $75 \%$ ) menilai sistem pendidikan nasional tidak 


Kredo 4 (2020)
KREDO: Jurnal Ilmiah Bahasa dan Sastra
Terakreditasi Sinta 4 berdasarkan Keputusan Direktorat
Jenderal Penguatan Riset dan Pengembangan,
Kementerian Riset, Teknologi dan Pendidikan Tinggi
Republik Indonesia
Nomor: 23/E/KPT/2019. 08 Agustus 2019
https://jurnal.umk.ac.id/index.php/kredo/index

mengembangkan dasar-dasar literasi, terutama menulis yang dipersepsi sebagai keterampilan paling sulit dikuasai (43.22\%), yang diikuti keterampilan berbicara $(28.64 \%)$, menyimak (21.11\%), dan membaca (7.04\%). Pernyataan yang diungkapkan di atas menjadi alasan adanya permasalahan dalam pembelajaran menulis di sekolah.

Ada beberapa faktor yang menyebabkan kurangnya keterampilan menulis. Hasil penelitian yang dilakukan oleh Warno (2009) mengungkapkan bahwa kurangnya keterampilan mahasiswa dalam menulis disebabkan oleh beberapa faktor di antaranya: 1) kurangnya kemampuan kebahasaan yang dimiliki siswa, seperti: pemahaman tentang kaidah atau aturan-aturan bahasa, baik yang mencakup masalah ejaan, pemilihan kosa kata, pembentukan kata, maupun penyusunan kalimat dan paragraf; 2) kurangnya kemampuan siswa dalam mengorganisasikan gagasan; 3) kurangnya kemampuan siswa dalam mengembangkan paragraf dengan baik; 4) kurangnya kemampuan siswa dalam memilih kata (diksi) secara tepat; 5) lemahnya minat belajar bahasa Indonesia di kalangan siswa; dan 6) kurangnya kesempatan siswa untuk berlatih secara terus-menerus melakukan kegiatan menulis. Pernyataan-pernyataan di atas menunjukkan kompleksitas permasalahan dalam pembelajaran menulis.

Untuk memperoleh data awal, dilakukan observasi sederhana di kelas Keterampilan Menulis Kreatif PBSI USD kelompok A dan B pada rentang bulan Februari-Maret 2020. Observasi tersebut dilakukan kurang lebih 2 kali pertemuan pada masing-masing kelas untuk mengetahui gambaran awal kondisi pembelajaran menulis kreattif yang berlangsung. Berdasarkan hasil pengamatan, pembelajaran menulis kreatif yang sudah berlangsung di PBSI USD penulis masih belum optimal. Hal itu dibuktikan dengan lebih banyaknya waktu yang digunakan mahasiswa untuk mendengarkan uraian contoh dan referensi dari dosen serta presentasi karya tulis fiksi, dibandingkan dengan praktik menulis. Padahal, pembelajaran menulis kreatif yang ideal harus memberikan banyak waktu pada mahasisawa untuk praktik berlatih menulis baik di dalam kelas maupun di luar kelas. Pernyataan itu sesuai dengan pendapat Warno (2009) bahwa kurangnya kesempatan siswa untuk berlatih menulis secara terus-menerus dapat menjadi salah satu penyebab kesulitan dalam menulis.

Berdasarkan hasil pengamatan tersebut, penulis meringkas bahwa pembelajaran menulis kreatif yang terjadi selama ini lebih banyak porsi untuk mendengarkan dan presentasi dibandingkan dengan praktik menulis. Hal itu berbanding terbalik dengan kenyataan yang diharapkan bahwa dalam pembelajaran menulis fabel dalam mata kuliah KMK adalah mahasiswa diberi kebebasan bereksplorasi, praktik menulis fabel, dan tidak hanya terbatas pada kegiatan mendegarkan materi dari belakang meja. Selain itu, diharapkan mahasiswa mampu menulis fabel yang mengandung nilai-nilai moral, mahasiswa dapat melakukan kegiatan pramenulis, menulis, dan pascamenulis yang mendukung, serta mahasiswa memiliki kesempatan dan fasilitas untuk 


Kredo 4 (2020)
KREDO: Jurnal Ilmiah Bahasa dan Sastra
Terakreditasi Sinta 4 berdasarkan Keputusan Direktorat
Jenderal Penguatan Riset dan Pengembangan,
Kementerian Riset, Teknologi dan Pendidikan Tinggi
Republik Indonesia
Nomor: 23/E/KPT/2019. 08 Agustus 2019
https://jurnal.umk.ac.id/index.php/kredo/index

menulis dengan berbagai macam rangkaian kegiatan pembelajaran. Hal itu didukung oleh pendapat Sobari yang menjelaskan bahwa aktivitas menulis sangat membutuhkan variasi dan cara pembelajaran yang dapat menumbuhkan minat dalam memproduksi tulisan yang berkualitas (Sobari 2015). Dengan begitu, penting bagi pendidik untuk menentukan model pembelajaran yang efektif untuk mewujudkan aktivitas menulis yang efektif bagi mahasiswa.

Penelitian ini memiliki rumusan masalah yaitu: 1) Apa saja faktor penyebab kesulitan mahasiswa PBSI USD dalam pembelajaran menulis fabel? 2) Bagaimana model pembelajaran menulis fabel yang diharapkan oleh mahasiswa? Sejalan dengan rumusan masalah, penelitian ini bertujuan untuk mendeskripsikan faktor penyebab kesulitan mahasiswa PBSI USD dalam pembelajaran menulis fabel dan mendeskripsikan model pembelajaran menulis fabel yang diharapkan oleh mahasiswa. Adapun manfaat yang diharapkan dari hasil penelitian ini adalah (1) secara teoretis, hasil penelitian ini dapat memberikan sumbangan informasi tentang kesulitan belajar, khususnya kesulitan menulis fabel. (2) Secara praktis, hasil penelitian ini ditujukan untuk beberapa pihak yang memiliki kepentingan terkait pembelajaran menulis fabel seperti mahasiswa, dosen, dan tim penyusun kurikulum dalam membuat keputusan yang mengacu pada perbaikan di masa depan.

\section{KAJIAN TEORI}

Dalam membahas hasil temuan, peneliti mengacu pada beberapa kajian teori seperti konsep menulis, konsep fabel, konsep menulis kreatif, dan konsep model pembelajaran. Kajian teori diuraikan sebagai berikut.

\section{a. Menulis Kreatif}

Menulis adalah mengungkapkan ide gagasan dalam pikiran dan rasa melalui bahasa (Heru Kurniawan dan Sutardi 2012). Suparno dan Yunus dalam Dalman menuliskan bahwa menulis merupakan suatu kegiatan penyampaian pesan (komunikasi) dengan menggunakan bahasa tulis sebagai alat atau medianya (Dalman 2016). Tarigan menuliskan bahwa menulis merupakan suatu keterampilan bahasa yang dipergunakan untuk berkomunikasi secara tidak langsung, tidak secara tatap muka dengan orang lain (Tarigan, \& Henry 1994). Dalman menuliskan bahwa menulis merupakan sebuah proses kreatif menuangkan gagasan dalam bentuk bahasa tulis dalam tujuan, misalnya memberitahu, meyakinkan, atau menghibur (Dalman 2016). Jadi, dari keempat pedapat tokoh tersebut, peneliti menyimpulkan bahwa menulis sebagai salah satu keterampilan berbahasa adalah proses pengungkapan ide gagasan dalam pikiran menggunakan bahasa tulis sebagai alatnya untuk dikomunikasikan kepada orang lain secara tidak langsung. 


Kredo 4 (2020)
KREDO: Jurnal Ilmiah Bahasa dan Sastra
Terakreditasi Sinta 4 berdasarkan Keputusan Direktorat
Jenderal Penguatan Riset dan Pengembangan,
Kementerian Riset, Teknologi dan Pendidikan Tinggi
Republik Indonesia
Nomor: 23/E/KPT/2019. 08 Agustus 2019
https://jurnal.umk.ac.id/index.php/kredo/index

\section{b. Kesulitan Menulis}

Menulis merupakan salah satu proses belajar. Oleh sebab itu mahasiswa yang mengalami kesulitan menulis kemungkinan juga memiliki masalah atau kesulitan dalam belajar. Kesulitan belajar dalam bahasa Inggris learning disability berarti ketidakmampuan belajar. Kata disability yang berarti kesulitan belajar memberikan kesan yang optimis bahwa seseorang masih mampu belajar . Di sisi lain, hambatanhambatan yang dialami mahasiswa dalam proses pembelajaran dapat menjadi ukuran untuk mengetahui penyebab kesulitan belajar mahasiswa (Suryani 2010). Menurut Ismail (2016), kesulitan belajar dapat diartikan sebagai suatu kondisi dalam proses belajar yang ditandai adanya hambatan-hambatan tertentu untuk mencapai hasil belajar. Kesulitan ini sering tampak sebagai kesulitan belajar yang disebabkan oleh tidak dikuasainya keterampilan prasyarat, yaitu keterampilan yang harus dikuasai terlebih dahulu sebelum menguasai keterampilan berikutnya (Ristiyani, E., \& Bahriah 2016). (Partowisastro 1986). Partowisastro (1986) berpendapat bahwa kasulitan belajar itu ada, kalau seorang mahasiswa itu jelas tidak memenuhi harapanharapan yang diisyaratkan oleh perguruan tinggi. Salah satu harapan tersebut adalah tercapainya hasil belajar mahasiswa yang optimal. Dengan menilik pendapat-pendapat tersebut, kesulitan menulis dapat dipahami sebagai sebuah kondisi yang ditandai dengan ditemukannya hambatan saat menulis sehingga menyebabkan hasil tulisan tidak optimal.

116 | Jurnal Kredo Vol. 4 No. 1 Oktober 2020

\section{c. Hakikat Fabel}

Perihal konsep fabel, fabel termasuk jenis cerita fiksi. Cerita fabel sering juga disebut cerita moral karena pesan yang ada didalamnya berkaitan dengan cerita moral. Hal tersebut sejalan dengan Danandjaja yang mengatakan bahwa cerita fabel menggunakan bintangan peliharaan dan hewan liar sebagai tokoh yang dapat berbicara dan berakal budi seperti manusia (Danandjaja 2002). Dengan demikian fabel dapat diartikan sebagai Cerita tentang kehidupan binatang berperilaku menyerupai manusia dan mengandung pesan moral. Secara umum, Struktur teks fabel terdiri dari orientasi, komplikasi, resolusi, dan koda. Sama dengan teks narasi fiksi lainnya, fabel terbentuk dari unsur-unsur pembangun. Unsur/elemen pembangun prosa fiksi oleh Sayuti (dibagi menjadi tiga bagian yaitu: (1) fakta cerita (plot, tokoh, dan latar), (2) sarana cerita (judul, sudut pandang serta gaya dan nada), dan (3) tema (A. Suminto Sayuti 2000). Dalam proses menulis, mahasiswa harus melewati serangkaian kegiatan. Heri (2010:17) mengatakan bahwa tahapantahapan yang perlu dilakukan dalam menulis fabel antara lain: menentukan tema dan judul, mengumpulkan bahan, menyeleksi bahan, dan membuat kerangka karangan. Menurut Suparno, ada dua kemampuan yang harus diperhatikan dalam menyusun karangan, yaitu kemampuan menyusun draf karangan yang utuh dan kemampuan menyunting (editing) karangan. Kedua kemampuan tersebut menjadi fokus dalam kegiatan menyusun karangan (Suparno 2011). Sementara, Komaidi (2007:180) mengatakan bahwa yang terdapat dalam kerangka cerita yakni 


Kredo 4 (2020)
KREDO: Jurnal Ilmiah Bahasa dan Sastra
Terakreditasi Sinta 4 berdasarkan Keputusan Direktorat
Jenderal Penguatan Riset dan Pengembangan,
Kementerian Riset, Teknologi dan Pendidikan Tinggi
Republik Indonesia
Nomor: 23/E/KPT/2019. 08 Agustus 2019
https://jurnal.umk.ac.id/index.php/kredo/index

setting, tokoh, alur cerita, masalah atau konflik, dan solusi atau pemecahan dari konflik (Komaidi 2007).

\section{d. Hambatan Menulis Fabel}

Dalam kegiatan berkomunikasi lewat tulisan, mahasiswa memiliki tantangan yang berbeda dari pada berkomunikasi dengan mengandalkan keterampilan berbicara. Jika dibandingkan dengan kegiatan berbicara, kegiatan menulis harus memenuhi beberapa syarat yang tidak berlaku bagi kegiatan berbicara agar penulisan itu bisa efektif, yaitu: pengorganisasian yang ketat pada pengembangan ide dan informasi, tingkat akurasi yang tinggi agar tidak ada keraguan makna, penggunaan sarana-sarana tatabahasa yang kompleks agar bisa membuat pembaca terfokus pada penekananpenekanan yang diberikan penulis, dan pemilihan kosakata, pola tatabahasa, dan struktur kalimat secara saksama agar bisa menciptakan gaya yang sesuai bagi tema dan bagi pembacanya nanti (Ghazali 2013). Maka, tak heran jika mahasiswa mengalami berbagai kesulitan dalam belajar menulis, khususnya belajar menulis fabel. Kesulitan pada umumnya dikualifikasikan dalam kesulitan dari faktor eksternal dan internal. Menyadari adanya kesulitan yang dialami mahasiswa dalam menulis fabel, maka kesulitan itu perlu untuk diteliti. Penelitian tersebut dilakukan untuk mengetahui secara pasti hal-hal yang menjadi kesulitan bagi mahasiswa. Dengan mengetahui hasil penelitian berupa kesulitan, maka dapat ditentukan tindak lanjut yang bisa dilakukan untuk mengatasi kesulitan dalam belajar menulis fabel tersebut.

\section{e. Hakikat Model Pembelajaran}

Model pembelajaran digunakan untuk membantu guru dalam menerapkan bahan ajar yang perlu mereka sampaikan kepada siswa. Dengan adanya model pembelajaran, guru mendapatkan beragam alternatif cara untuk menyampaikan informasi kepada siswa (Wahab,2005). Model pembelajaran merupakan suatu kerangka konseptual yang berisi prosedur sistematik (Suprijono, 2009) dan mengorganisasikan pengalaman belajar siswa untuk mencapai tujuan belajar tertentu (Wilson 2013) yang berfungsi sebagai pedoman bagi guru (Sagala, 2010). Dengan demikian model pembelajaran dapat dipahami sebagai seperangkat konsep yang berisi cara atau prosedur untuk menyampaikan materi dan menghasilkan pengalaman belajar tertentu.

\section{f. Karakteristik Model Pembelajaran}

Untuk membedakan model pembelajaran dan elemen-elemen pembelajaran yang lain, beberapa tokoh berpendapat mengenai karakteristik dan sifat model pembelajaran. Iru, La dan Arihi (2012) mengemukakan bahwa model pembelajaran dikembangkan atas beberapa asumsi, yaitu (1) mengajar adalah upaya menciptakan lingkungan yang sesuai, dimana terdapat berbagai lingkungan mengajar yang memiliki saling ketergantungan; (2) terdapat berbagai komponen yang meliputi isi, keterampilan peran-peran mengajar, hubungan sosial, bentuk-bentuk kegiatan, sarana/fasilitas fisik dan 


Kredo 4 (2020)
KREDO: Jurnal Ilmiah Bahasa dan Sastra
Terakreditasi Sinta 4 berdasarkan Keputusan Direktorat
Jenderal Penguatan Riset dan Pengembangan,
Kementerian Riset, Teknologi dan Pendidikan Tinggi
Republik Indonesia
Nomor: 23/E/KPT/2019. 08 Agustus 2019
https://jurnal.umk.ac.id/index.php/kredo/index

penggunaannya, yang keseluruhannya membentuk sebuah sistem lingkungan yang bagian-bagiannya saling berinteraksi, yang mendesak perilaku seluruh partisipan, baik guru maupun siswa; (3) antara bagian-bagian tersebut akan menghasilkan bentuk lingkungan yang berbedamdengan hasil yang berbeda pula; dan (4) karena model mengajar menciptakan lingkungan, maka model menyediakan spesifikasi yang masih bersifat kasar untuk lingkungan dalam proses belajar-mengajar di kelas. Dari asumsi tersebut maka model pembelajaran memiliki komponen: fokus, sintaks, sistem sosial, dan sistem pendukung (Iru, La dan Arihi, 2012). Model-model pembelajaran memiliki ciri-ciri umum, yaitu (1) memiliki prosedur yang sistematis, (2) hasil belajar diterapkan secara khusus, (3) ada ukuran keberhasilan, dan (4) mempunyai cara interaksi dengan lingkungan (Iru dan Arihi, 2012: 8). Chauchan (Iru dan Arihi, 2012: 9) menyebutkan fungsi model pembelajaran adalah (1) sebagai pedoman, (2) sebagai alat bantu dalam mengembangkan kurikulum, (3) sebagai acuan dalam menetapkan bahan pembelajaran, dan (4) untuk membantu perbaikan dalam mengajar.

\section{g. Model Pembelajaran Environmental Learning}

Salah satu contoh model pembelajaran yang dapat diterapkan dalam pembelajaran menulis fabel adalah model pembelajaran environmental learning. Scott and Gough menyatakan bahwa model environmental learning adalah pembelajaran yang muncul dari lingkungan atau ide-ide tentang

118 | Jurnal Kredo Vol. 4 No. 1 Oktober 2020 lingkungan (Gough, A. \& Gough 1969). Tujuan penerapan model environmental learning adalah agar mahasiswa dengan mudah berinteraksi dengan bahan pelajaran yang telah disusun dan disesuaikan dengan model pembelajaran. Bahan pembelajaran yang disajikan disusun dengan melibatkan lingkungan sekitar. Dengan begitu, pembelajaran menulis fabel bisa dilakukan tidak hanya di dalam kelas, tetapi juga di luar kelas agar mahasiswa lebih aktif dalam proses pembelajaran. Sementara, Ali dalam Wengkang (2016) menyatakan bahwa model environmental learning adalah model pembelajaran yang mengedepankan pengalaman mahasiswa dalam hubungannya dengan alam sekitar, sehingga mahasiswa dapat dengan mudah memahami isi materi yang disampaikan. Pendapat ini menunjukkan bahwa penerapan model environmental learning dalam pembelajaran bertujuan untuk meningkatkan kepedulian mahasiswa terhadap lingkungan sekitar. Dengan demikian, model environmental learning mengarah pada pembelajaran berbasis lingkungan yang menghendaki agar kegiatan belajar tidak hanya dibatasi oleh dinding, tetapi bagaimana lingkungan itu dapat dimanfaatkan sebagai sumber belajar, atau menghadirkan lingkungan dalam pembelajaran sehingga materi yang diangkat berkaitan erat dengan lingkungan. Menilik uraian tentang environmental learning, adanya kegiatan atau tugas-tugas yang mengacu pada model pembelajaran tersebut baik dalam kegiatan pramenulis, menulis, atau pascamenulis dapat menjadi alternatif 


Kredo 4 (2020)
KREDO: Jurnal Ilmiah Bahasa dan Sastra
Terakreditasi Sinta 4 berdasarkan Keputusan Direktorat
Jenderal Penguatan Riset dan Pengembangan,
Kementerian Riset, Teknologi dan Pendidikan Tinggi
Republik Indonesia
Nomor: 23/E/KPT/2019. 08 Agustus 2019
https://jurnal.umk.ac.id/index.php/kredo/index

baru untuk mengatasi kesulitan menulis fabel mahasiswa.

Kegiatan menulis fabel membantu mahasiswa dalam mengembangkan keterampilan menulis narasi fiksi dan mengasah kreativitas. Dalam mempersiapkan pembelajaran menulis fabel, dosen perlu merancang pembelajaran dengan model pembelajaran tertentu untuk menciptakan pembelajaran yang bermakna bagi mahasiswa. Model pembelajaran digunakan untuk membantu dosen dalam menerapkan bahan ajar yang perlu mereka sampaikan kepada mahasiswa. Dengan adanya model pembelajaran, dosen mendapatkan beragam alternatif cara untuk menyampaikan informasi kepada mahasiswa (Wahab 2008). Dengan demikian model pembelajaran dapat dipahami sebagai seperangkat konsep yang berisi cara atau prosedur untuk menyampaikan materi dan menghasilkan pengalaman belajar tertentu. Menilik pentingnya peran model pembelajaran, dosen perlu mengetahui berbagai harapan mahasiswa tentang model pembelajaran menulis fabel yang ideal bagi mereka. Informasi tersebut akan berguna sebagai acuan untuk dosen dalam bereksplorasi untuk mengembangkan berbagai komponen pembelajaran yang berbasis model pembelajaran tertentu agar pembelajaran menulis fabel pada mata kuliah menulis kreatif menjadi lebih efektif dan bermakna.

\section{METODE PENELITIAN}

Jenis penelitian ini adalah penelitian deskriptif kualitatif. Penelitian ini bertujuan untuk menggali faktor penyebab kesulitan mahasiswa PBSI USD dalam pembelajaran menulis fabel dan mendeskripsikan model pembelajaran menulis fabel yang diharapkan oleh mahasiswa. Adapun, sumber data dari penelitian ini adalah mahasiswa yang tergabung dalam mata kuliah Keterampilan Menulis Kreatif kelas B prodi PBSI USD tahun ajaran 2019/2020 yang berjumlah 17 orang. Teknik pengumpulan data dilakukan dengan membagikan kuesioner terbuka. Kuesioner tersebut berisi 2 buah pertanyaan esensial. Kuesioner tersebut digunakan sebagai alat dalam penelitian ini untuk menanyakan persepsi mahasiswa terhadap kesulitan yang mereka hadapi dalam menulis fabel dan model pembelajaran yang mereka harapkan. Pada pertanyaan pertama, setiap orang diminta untuk memberikan sepuluh item jawaban yang menunjukkan kesulitan mereka dalam menulis fabel. Sementara, pertanyaan kedua dapat dijawab dengan jawaban yang menunjukkan kriteria model pembelajaran ideal yang mereka harapakan dalam pembelajaran menulis fabel. Setelah semua jawaban terkumpul, peneliti mengidentifikasi dan mengkategorikan setiap jawaban. Analisis data dilakukan dengan menggunakan Microsoft Excel untuk menghitung dan menemukan persentase dari setiap kategori. Data yang telah diolah tersebut disajikan dalam tabel sebagai hasil penelitian untuk kemudian didiskusikan dalam subbab pembahasan. 


Kredo 4 (2020)
KREDO: Jurnal Ilmiah Bahasa dan Sastra
Terakreditasi Sinta 4 berdasarkan Keputusan Direktorat
Jenderal Penguatan Riset dan Pengembangan,
Kementerian Riset, Teknologi dan Pendidikan Tinggi
Republik Indonesia
Nomor: 23/E/KPT/2019. 08 Agustus 2019
https://jurnal.umk.ac.id/index.php/kredo/index

\section{HASIL DAN PEMBAHASAN}

Tabel 2 di bawah menyajikan faktor-faktor yang menyebabkan mahasiswa PBSI USD kesulitan dalam menulis fabel. Data tersebut telah dirangkum berdasarkan respon mahasiswa terhadap kuesioner terbuka yang berbunyi "Fabel adalah salah satu jenis tulisan fiksi yang dipelajari pada mata kuliah Menulis Kreatif. Mahasiswa seringkali mengalami berbagai kesulitan dalam menulis fabel. Tuliskanlah sepuluh kesulitan yang kamu hadapi saat menulis fabel!". Namun, kasus-kasus ini tidak dapat digeneralisasi untuk semua mahasiswa di program studi tersebut, tetapi mewakili mayoritas mahasiswa khususnya, untuk mahasiswa yang tergabung pada mata Kuliah Menulis Kreatif tahun akademik 2019/2020 kelompok belajar B.

Tabel 2. Faktor-faktor yang Menyebabkan Kesulitan Menulis Fabel oleh Mahasiswa

\begin{tabular}{|c|c|c|c|}
\hline No. & Kategori Faktor & $\begin{array}{l}\text { Fre- } \\
\text { kuesi }\end{array}$ & $\begin{array}{l}\text { Persen- } \\
\text { tase }(\%)\end{array}$ \\
\hline 1. & $\begin{array}{l}\text { Kesulitan untuk menemukan } \\
\text { objek (binatang) yang menarik } \\
\text { untuk dijadikan } \\
\text { tokoh/karakter. }\end{array}$ & 5 & $4 \%$ \\
\hline 2. & $\begin{array}{l}\text { Kurangnya kreativitas dan } \\
\text { daya imajinatif dalam } \\
\text { menulis. }\end{array}$ & 5 & $4 \%$ \\
\hline 3. & $\begin{array}{l}\text { Kesulitan untuk mencari } \\
\text { sumber inspirasi. }\end{array}$ & 7 & $5 \%$ \\
\hline & $\begin{array}{l}\text { Kesulitan untuk mendapatkan } \\
\text { ide/topik. }\end{array}$ & 16 & $12 \%$ \\
\hline & $\begin{array}{l}\text { Kesulitan dalam mencari } \\
\text { informasi pendukung untuk } \\
\text { menulis fabel. }\end{array}$ & 6 & $4 \%$ \\
\hline & $\begin{array}{l}\text { Mengalami kebingungan } \\
\text { dalam mengubah pengalaman } \\
\text { indrawi atau ide ke dalam } \\
\text { sebuah tulisan. }\end{array}$ & 3 & $2 \%$ \\
\hline & $\begin{array}{l}\text { Kesulitan memilih } \\
\text { kata/diksi. }\end{array}$ & 10 & $7 \%$ \\
\hline & $\begin{array}{l}\text { Kesulitan } \\
\text { berkonsentrasi. }\end{array}$ & 2 & $1 \%$ \\
\hline & $\begin{array}{l}\text { Kesulitan untuk melawan rasa } \\
\text { malas untuk mulai menulis } \\
\text { fabel. }\end{array}$ & 7 & $5 \%$ \\
\hline
\end{tabular}

120 | Jurnal Kredo Vol. 4 No. 1 Oktober 2020

\begin{tabular}{|c|c|c|}
\hline $\begin{array}{l}\text { 10. Kurangnya pemahaman } \\
\text { mengenai struktur fabel. }\end{array}$ & 11 & $8 \%$ \\
\hline $\begin{array}{l}\text { 11. Kesulitan untuk mengaitkan } \\
\text { kalimat satu dengan kalimat } \\
\text { lain dan paragraf satu dengan } \\
\text { lainnya. (kohesi rau } \\
\text { koherensi?) }\end{array}$ & 10 & $7 \%$ \\
\hline $\begin{array}{l}\text { 12. Kesulitan membuat bagian } \\
\text { orientasi. }\end{array}$ & 5 & $4 \%$ \\
\hline $\begin{array}{l}\text { 13. } \text { Kesulitan membuat bagian inti } \\
\text { cerita (komplikasi dan } \\
\text { resolusi. }\end{array}$ & 3 & $2 \%$ \\
\hline 14. Kesulitan membuat koda. & 5 & $4 \%$ \\
\hline $\begin{array}{l}\text { 15. Kesulitan membuat judul yang } \\
\text { menarik. }\end{array}$ & 6 & $4 \%$ \\
\hline $\begin{array}{l}\text { 16. Kesulitan menciptakan unsur } \\
\text { latar. }\end{array}$ & 2 & $1 \%$ \\
\hline $\begin{array}{l}\text { 17. Kesulitan menentukan jenis } \\
\text { alur dan membuat alur. }\end{array}$ & 8 & $6 \%$ \\
\hline $\begin{array}{l}\text { 18. Sulit menentukan ragam } \\
\text { bahasa yang menarik (Faktor } \\
\text { kebahasaan).(gaya bahasa) }\end{array}$ & 7 & $5 \%$ \\
\hline $\begin{array}{l}\text { 19. Kurangnya pemahaman } \\
\text { tentang kaidah PUEBI. }\end{array}$ & 3 & $2 \%$ \\
\hline $\begin{array}{l}\text { 20. Ketakutan untuk membuat } \\
\text { kesalahan dalam penulisan. }\end{array}$ & 1 & $1 \%$ \\
\hline $\begin{array}{l}\text { 21. Kurangnya kepercayaan diri } \\
\text { sehingga kerap mengganti } \\
\text { tulisan beberapa kali. }\end{array}$ & 3 & $2 \%$ \\
\hline $\begin{array}{l}\text { 22. Kurangnya perbendaharaan } \\
\text { kosakata. }\end{array}$ & 1 & $1 \%$ \\
\hline $\begin{array}{l}\text { 23. Kurangnya motivasi dalam } \\
\text { menulis. }\end{array}$ & 5 & $4 \%$ \\
\hline $\begin{array}{l}\text { 24. Kesulitan untuk } \\
\text { mempublikasikan fabel. }\end{array}$ & 1 & $1 \%$ \\
\hline $\begin{array}{l}\text { 25. Kesulitan menentukan amanat } \\
\text { atau pesan moral yang hendak } \\
\text { disampaikan pada pembaca. }\end{array}$ & 1 & $1 \%$ \\
\hline $\begin{array}{l}\text { 26. Kurangnya waktu karena } \\
\text { banyak tugas lainnya. }\end{array}$ & 3 & $2 \%$ \\
\hline Jumlah & 136 & $100 \%$ \\
\hline
\end{tabular}

Tabel di atas menunjukkan bahwa kesulitan mahasiswa dalam menulis fabel diwakili dengan 26 indikator. Adapun indikator-indikator tersebut 


Kredo 4 (2020)
KREDO: Jurnal Ilmiah Bahasa dan Sastra
Terakreditasi Sinta 4 berdasarkan Keputusan Direktorat
Jenderal Penguatan Riset dan Pengembangan,
Kementerian Riset, Teknologi dan Pendidikan Tinggi
Republik Indonesia
Nomor: 23/E/KPT/2019. 08 Agustus 2019
https://jurnal.umk.ac.id/index.php/kredo/index

dapat digolongkan ke dalam faktor internal dan eksternal. Hal itu didukung oleh pendapat Slameto (2010) yang menyatakan bahwa faktor-faktor yang mempengaruhi belajar banyak jenisnya, tetapi dapat digolongkan menjadi dua yaitu faktor internal dan eksternal. Secara umum, kesulitan mahasiswa PBSI USD dalam menulis fabel yang datang dari faktor internal yang dirangkum dalam empat hal sebagai berikut. Pertama, mahasiswa lemah dalam hal minat dan motivasi. Motivasi sangat diperlukan untuk mendukung keberhasilan mahasiswa dalam pembelajaran menulis fabel. Hal itu didukung oleh Syah yang mengatakan bahwa minat atau motivasi merupakan salah satu faktor yang mempengaruhi kualitas dan pencapaian hasil belajar siswa dalam bidang-bidang studi tertentu (Syah 2007). Apabila seseorang mempunyai minat yang tinggi terhadap sesuatu hal maka akan terus berusaha untuk melakukan sehingga apa yang diinginkannya dapat tercapai sesuai dengan keinginannya (Purwanto 2013). Kedua, mahasiswa kesulitan mencari insirpirasi.

Ketiga, mahasiswa kurang pengetahuan mendalam tentang konsep fabel; misalnya, tentang struktur, alur, dan lain-lain. Dalam menulis fabel, mahasiswa tidak cukup hanya mengandalkan keterampikan dalam menulis saja, tetapi mahasiswa juga harus memahami seluk-beluk fabel itu sendiri. Hal itu sejalan dengan yang dikatakan Akhadiah bahwa tidaklah berlebihan jika kemampuan menulis disebut sebagai kemampuan berbahasa yang kompleks, yang menuntut sejumlah pengetahuan dan keterampilan
(Akhadiah 1988). Keempat, mahasiswa kurang memiliki keterampilan dalam berbahasa tulis seperti diksi, koherensi, gaya bahasa, dan penguasaan PUEBI. Diksi adalah salah satu hal yang harus diperhatikan dalam menulis. Apabila diksi yang digunakan tidak sesuai dengan situasi dan kondisi, dapat mengakibatkan pembaca salah pengertian dalam memahami maksud si penulis (Yahya, Andayani 2018). Oleh karena itu, dalam menulis fabel mahasiswa hendaknya menggunakan diksi yang tepat agar maksud penulis dapat dipahami dengan cermat oleh pembaca.

Di samping diksi, kohesi dan koherensi tulisan menjadi suatu kesulitan bagi mahasiswa dalam hal menulis. Hal ini sejalan dengan pendapat Maslakhah dalam Wiedarti yang menyatakan bahwa kesulitan menyusun paragraf yang baik, kohesif, dan koheren yang biasa dialami oleh sebagian besar penulis (Wiedarti 2005). Beberapa memang mampu menyusun paragraf yang baik, namun tidak sedikit juga yang susunanya kurang baik. Hal itu didukung oleh hasil penelitian Lestari (2019) bahwa karangan narasi mahasiswa Teknik angkatan 2017 masih belum menunjukkan persyaratan kohesi dan koherensi yang baik, hal ini disebabkan kurangnya pemahaman mahasiswa dalam hal mamadukan kalimat satu dengan kalimat lainnya, belum adanya kelogisan dalam penyusunan paragraf.

Hambatan dalam menulis sesuai kajian Sumantri adalah kurangnya kemampuan dalam penguasaan teknik penulisan (Usep Pahing Sumantri 2004). Umumnya tidak semua orang dapat menyusun kalimat dengan ragam baku 


Kredo 4 (2020)
KREDO: Jurnal Ilmiah Bahasa dan Sastra
Terakreditasi Sinta 4 berdasarkan Keputusan Direktorat
Jenderal Penguatan Riset dan Pengembangan,
Kementerian Riset, Teknologi dan Pendidikan Tinggi
Republik Indonesia
Nomor: 23/E/KPT/2019. 08 Agustus 2019
https://jurnal.umk.ac.id/index.php/kredo/index

(tidak dapat menyusun kalimat efektif) dengan baik. Akibatnya, ditemukan cukup banyak kalimat tidak baku dalam tulisan (Wiedarti 2005). Kesulitankesulitan tersebut diperkuat dengan pendapat Maslakhah dalam Wiedarti yang mengemukakan bahwa ada beberapa kesulitan yang dialami saat menulis, di antaranya yaitu: (1) kesulitan menentukan topik atau persoalan yang akan ditulis, (2) kesulitan mencari atau menemukan bahan tulisan ataupun referensi, (3) kesulitan menyusun kalimat yang baku (efektif), dan (4) kesulitan menyusun paragraf yang baik (Wiedarti 2005).

Sementara, kesulitan yang disebabkan oleh faktor eksternal yang datang dari luar diri mahasiswa dirangkum dalam beberapa indikator. Pertama, mahasiswa mengalami gangguan konsentrasi. Hal itu didukung oleh pendapat Slameto yang mengatakan bahwa kondisi dan letak gedung sekolah yang buruk seperti di dekat pasar/keramaian, dan alat-alat belajar yang berkualitas rendah merupakan faktor eksternal yang tidak mendukung aktivitas belajar siswa, sehingga menjadi penyebab kesulitan belajar (Slameto 2010). Jadi, upaya menjaga konsentrasi merupakan hal penting yang harus diperhatikan dalam menulis fabel. Kedua, mahasiswa kekurangan waktu dalam pengerjaan. Seorang penulis perlu berlatih untuk disiplin pada waktu yang telah ditargetkan agar tulisan akan dibuat benar-benar dapat terselesaikan (Syawqi 2017). Ketiga, mahasiswa kesulitan untuk publikasi karya. Keberhasilan dalam publikasi karya akan memberikan keyakinan pada penulis bahwa ia mampu. Hal itu akan menyebabkan penulis ketagihan dan mendorong semangatnya untuk kembali menulis serta meningkatkan kepercayaan dirinya (Syawqi 2017).

Adapun, kesulitan yang paling dominan dialami oleh mahasiswa adalah kesulitan untuk mendapatkan ide/topik yaitu dialami oleh 16 mahasiswa dari total 17 responden dengan persentase sebesar 12\%. Kesulitan mahasiswa dalam menentukan topik tersebut bukan tanpa alasan. Pasalnya, hal tersebut didukung oleh pandangan Maslakhah dalam Wiedarti yang mengatakan bahwa kesulitan menentukan topik atau persoalan yang akan ditulis merupakan masalah klise yang umum dijumpai dan dialami oleh setiap orang yang akan menulis (Wiedarti 2005). Setiap orang merasa bahwa tidak ada topik atau persoalan yang bagus, yang menarik, dan yang cocok untuk ditulis. Kesulitan lain yang mayoritas dialami mahasiswa di antaranya: (1) kurangnya pemahaman mengenai struktur fabel (dengan persentase 8\%), (2) kesulitan memilih kata-kata/diksi (dengan persentase 7\%), dan (3) kesulitan untuk mengaitkan kalimat satu dengan kalimat lain dan paragraf satu dengan lainnya (dengan persentase 7\%).

Model pembelajaran merupakan salah satu elemen penting yang harus diperhatikan dalam merencanakan pembelajaran. Hamalik mengatakan bahwa cara yang digunakan oleh pengajar dalam memberikan pelajar dan bimbingan sering kali besar pengaruhnya terhadap siswa dalam kesuksesan belajarnya (Hamalik 2005). Penggunaan model pembelajaran yang kuang menarik dapat membuat siswa tidak bersemangat dalam mengikuti 


Kredo 4 (2020)
KREDO: Jurnal Ilmiah Bahasa dan Sastra
Terakreditasi Sinta 4 berdasarkan Keputusan Direktorat
Jenderal Penguatan Riset dan Pengembangan,
Kementerian Riset, Teknologi dan Pendidikan Tinggi
Republik Indonesia
Nomor: 23/E/KPT/2019. 08 Agustus 2019
https://jurnal.umk.ac.id/index.php/kredo/index

pembelajaran (Sofia, Fathurohman 2020). Jadi, dosen sebagai pengajar juga perlu merancang pembelajaran yang mendukung. Rancangan pembelajaran yang ideal akan didapatkan apabila pengajar juga memperhatikan kebutuhan dan harapan-harapan peserta didik terhadap pembelajaran itu sendiri. Oleh sebab itu, peniliti juga mengumpulkan data terkait harapan mahasiswa erhadap model pembelajaran menulis fabel yang diideal. Hasil temuan tersebut dapat digunakan sebagai bahan pertimbangan pengajar dalam merancang pembelajaran menulis fabel pada mata kuliah Keterampilan Menulis Kreatif (KMK).

Adapun, harapan mahasiswa PBSI USD yang tegabung dalam kelas KMK kelompok B terhadap model pembelajaran yang diideal untuk materi menulis fabel diwakili oleh data-data berupa indikator. Data tersebut dirangkum berdasarkan jawabanjawaban mahasiswa terhadap pertanyaan kuesioner terbuka yang berbunyi "Fabel adalah cerita fiksi yang menggunakan binatang sebagai tokoh utamanya. Binatang tersebut dibuat seolah-olah memiliki watak dan perilaku layaknya manusia dan juga memiliki keterkaitan dengan lingkungan sekitar. Oleh sebab itu, penggunaan model pembelajaran tertentu sangat penting dalam pembelajaran menulis fabel. Menurut Anda, model pembelajaran seperti apa yang dibutuhkan dalam menulis fabel?". Hasil temuan disajikan dalam tabel berikut ini.
Tabel 3. Model Pembelajaran Menulis Fabel yang diharapkan oleh Mahasiswa

\begin{tabular}{llcc}
\hline No. & \multicolumn{1}{c}{ Kategori Faktor } & Frekuensi & $\begin{array}{c}\text { Persen- } \\
\text { tase (\%) }\end{array}$ \\
\hline $1 . \quad \begin{array}{l}\text { Model pembelajaran yang } \\
\text { tidak terlalu serius dan } \\
\text { santai sehingga dapat } \\
\text { menumbuhkan kreativitas } \\
\text { dan imajinasi. }\end{array}$ & $8 \%$ \\
\hline & $\begin{array}{l}\text { Model pembelajaran yang } \\
\text { memanfaatkan video atau } \\
\text { gambar-gambar yang } \\
\text { menarik. }\end{array}$ & \\
\hline Model pembelajaran \\
dengan berkelompok atau \\
kerja tim.
\end{tabular}

Tabel 3 di atas menunjukkan bahwa harapan mahasiswa terkait model pembelajaran ideal untuk diterapkan dalam pembelajaran menulis fabel diwakili oleh 8 indikator. Adapun, model pembelajaran yang paling dominan diharapkan oleh mahasiswa adalah model pembelajaran yang di dalamnya 


Kredo 4 (2020)
KREDO: Jurnal Ilmiah Bahasa dan Sastra
Terakreditasi Sinta 4 berdasarkan Keputusan Direktorat
Jenderal Penguatan Riset dan Pengembangan,
Kementerian Riset, Teknologi dan Pendidikan Tinggi
Republik Indonesia
Nomor: 23/E/KPT/2019. 08 Agustus 2019
https://jurnal.umk.ac.id/index.php/kredo/index

terdapat kegiatan survei ke lapangan atau lingkungan hidup untuk memperoleh informasi dan gambaran nyata tentang hewan dan sifat-sifat dasar manusia untuk dibuat fabel. Indikator tersebut diharapkan oleh 7 mahasiswa dari total 17 responden dengan persentase sebesar $28 \%$. Bagi mahasiswa, informasi atau fakta hasil temuan dari proses survei lapangan tersebut dapat membantu mereka dalam menulis fabel. Hal itu diperkuat dengan pendapat Sambodja yang menyatakan bahwa cara termudah untuk menulis fiksi (sastra) adalah menulis cerita dari fakta yang ada (Sambodja 2007).

Model pembelajaran lain yang mayoritas diharapkan oleh mahasiswa meliputi: 1) model pembelajaran yang memanfaatkan video atau gambargambar menarik (dengan persentase $20 \%$ ), 2) model pembelajaran dengan cara berkelompok atau kerja tim (dengan persentase 16\%), 3) model pembelajaran yang memanfaatkan contoh-contoh fabel (dengan persentase 12\%). Sementara, harapan lain tentang model pembelajaran menulis fabel yang ideal berhubungan dengan pembelajaran yang santai, menyenangkan, memanfaatkan ruang terbuka selain kelas, dan tidak membatasi tema cerita.

Dengan adanya temuan tersebut, pengajar diharapkan mampu mempertimbangkan hasil temuan untuk merancang pembelajaran menulis fabel yang lebih efektif. Dengan begitu keberhasilan mahasiswa dalam menulis fabel selain ditunjang kematangan kemampuan pribadi mahasiswa, juga dapat didukung oleh proses pembelajaran atau latihan yang efektif. Hal tersebut sejalan dengan pendapat
Akadiah bahwa keterampilan menulis bukanlah kemampuan yang diwariskan secara turun-temurun, akan tetapi merupakan hasil proses belajar mengajar dan ketekunan berlatih (Akhadiah 1988). Jadi, keterampilan menulis itu mengalami proses pertumbuhan melalui latihan. Dengan demikian, untuk memperoleh keterampilan menulis tidak cukup dengan mempelajari tata bahasa dan mempelajari pengetahuan tentang teori menulis, melainkan tumbuh melalui proses pelatihan.

Berdasarkan analisis kebutuhan tentang model pembelajaran menulis fabel yang diharapkan mahasiswa tersebut, salah satu model pembelajaran yang disarankan untuk diterapkan dalam pembelejaran menulis fabel adalah model environmental learning. Model tersebut dipilih sebagai pedoman untuk mengembangkan kegiatan pembelajaran dan perangkat pembelajaran lainnya seperti mengembangkan instrumen evaluasi menulis fabel. Gough and Gough menyatakan bahwa model environmental learning adalah pembelajaran yang muncul dari lingkungan atau ide-ide tentang lingkungan (Gough, A. \& Gough 1969). Dengan demikian, kegiatan yang disajikan dalam proses pembelajaran dapat menuntun siswa untuk berintraksi dengan lingkungan hidup sesuai dengan yang diharapkan mahasiswa dalam data analisis kebutuhan.

Di sisi lain, peneliti juga mengumpulkan informasi tentang berbagai teori tahapan menulis. Peneliti memilih tahapan menulis karangan yang dipaparkan oleh Dalman. Dalman menuliskan bahwa kegiatan menulis terdiri dari tiga tahapan yaitu 


Kredo 4 (2020)
KREDO: Jurnal Ilmiah Bahasa dan Sastra
Terakreditasi Sinta 4 berdasarkan Keputusan Direktorat
Jenderal Penguatan Riset dan Pengembangan,
Kementerian Riset, Teknologi dan Pendidikan Tinggi
Republik Indonesia
Nomor: 23/E/KPT/2019. 08 Agustus 2019
https://jurnal.umk.ac.id/index.php/kredo/index

pramenulis, menulis, dan pascamenulis (Dalman 2016). Model pembelajaran tersebut dapat diintegrasikan dengan tahapan menulis menurut Dalman sehingga mampu menghasilkan gambaran prosedur pembelajaran sebagai berikut.

Tabel 4. Rancangan Kegiatan Menulis Fabel

\begin{tabular}{lcl}
\hline \multicolumn{1}{c}{ Tahapan } & $\begin{array}{c}\text { Langkah } \\
\text { ke- }\end{array}$ & \multicolumn{1}{c}{ Kegiatan } \\
\hline Prapenulisan & 1 & Eksplorasi lingkungan \\
\cline { 2 - 3 } & 2 & $\begin{array}{l}\text { Melaporkan hasil eksplorasi } \\
\text { lingkungan }\end{array}$ \\
\cline { 2 - 3 } & 3 & $\begin{array}{l}\text { Menentukan tema, tokoh, } \\
\text { latar, pesan moral, dan unsur } \\
\text { pembangun lainnya untuk } \\
\text { menulis fabel berdasarkan } \\
\text { ide yang ditemukan pada } \\
\text { kegiatan eksplorasi } \\
\text { lingkungan. }\end{array}$ \\
\cline { 2 - 4 } & & $\begin{array}{l}\text { Membuat kerangka cerita } \\
\text { dengan berpedoman pada } \\
\text { struktur fabel. }\end{array}$ \\
\hline Penulisan & & $\begin{array}{l}\text { Mengembangkan kerangka } \\
\text { cerita ke dalam paragraf- } \\
\text { paragraf dengan } \\
\text { memperhatikan unsur-unsur } \\
\text { pembangun dan ciri } \\
\text { kebahasaan fabel. }\end{array}$ \\
& & \\
& 5 & $\begin{array}{l}\text { Menyunting dan } \\
\text { memperbaiki tulisan fabel } \\
\text { yang telah dibuat. }\end{array}$ \\
& & $\begin{array}{l}\text { Mempublikasikan hasil } \\
\text { fabel. }\end{array}$ \\
\hline
\end{tabular}

\section{SIMPULAN}

Setelah menganalisis data, peneliti mengungkapkan faktor-faktor yang menyebabkan mahasiswa PBSI USD kesulitan dalam menulis fabel sebagai berikut. 1) Mayoritas siswa mengalami kendala internal yang berhubungan dengan minat dan motivasi. 2) Mahasiswa kesulitan untuk mencari inspirasi. 3) Mayoritas siswa kurang memiliki pengetahuan mendalam tentang konsep fabel; misalnya, tentang struktur, alur, dan lain-lain. 4) Mahasiswa mengalami kesulitan yang berhubungan dengan keterampilan berbahasa seperti diksi, koherensi, gaya bahasa, dan penguasaan PUEBI. 5) Mahasiswa terkendala faktor eksternal seperti kurang konsentrasi, kesulitan publikasi, dan kurangnya ketersediaan waktu yang diberikan untuk menulis. Oleh karena itu, temuan penelitian ini jelas menunjukkan bahwa mahasiswa masih perlu diperhatikan dalam hal dorongan motivasi, strategi pembelajaran, dan variabel terkait lainnya.

Selain itu, hasil ini juga menunjukkan bahwa model pembelajaran menulis fabel yang didambakan mahasiswa adalah model pembelajaran yang didalamnya mencakup kegiatan survei ke lapangan atau lingkungan hidup untuk memperoleh gambaran nyata dan informasi tentang hewan dan sifat-sifat dasar manusia sebagai sumber inspirasi dan informasi untuk menulis fabel. Hal itu dapat menjadi pertimbangan pendidik dalam memilih model pembelejaran tertentu contohnya model pembelajaran environmental learning atau model lain yang berbasis alam. Hasil temuan itu dapat menjadi referensi bagi pendidik untuk menyusun rancangan pembelajaran kedepanya yang lebih baik dengan memperhatikan kesulitan yang dihadapi mahasiswa dan harapan mereka tentang model pembelajaran yang cocok bagi mereka dalam menulis fabel. 


Kredo 4 (2020)
KREDO: Jurnal Ilmiah Bahasa dan Sastra
Terakreditasi Sinta 4 berdasarkan Keputusan Direktorat
Jenderal Penguatan Riset dan Pengembangan,
Kementerian Riset, Teknologi dan Pendidikan Tinggi
Republik Indonesia
Nomor: 23/E/KPT/2019. 08 Agustus 2019
https://jurnal.umk.ac.id/index.php/kredo/index

\section{DAFTAR PUSTAKA}

A. Suminto Sayuti. 2000. Berkenalan Dengan Prosa Fiksi. Yogyakarta: Gama Media. Akhadiah, Sabarti. 1988. Pembinaan Kemampuan Menulis Bahasa Indonesia. Jakarta: Penerbit Erlangga.

Alwasilah, A. Chaedar. 2002. "Artikel MKDU Bahasa Indonesia Gagal: Studi Kasus Penulisan Skripsi." In Kongres Linguistik Nasional X, , 80-83.

Arsanti, Meilan. 2018. "Pengembangan Bahan Ajar Mata Kuliah Penulisan Kreatif Bermuatan Nilai-Nilai Pendidikan Karakter Religius Bagi Mahasiswa Prodi PBSI, FKIP, UNISSULA.” Jurnal Kredo 1(2): 71-90.

Dalman, H. 2016. Keterampilan Menulis. Jakarta: Rajawali Press.

Danandjaja, James. 2002. Folklor Indonesia: Ilmu Gosip, Dongeng, Dan Lain-Lain. Jakarta: PT Pustaka Utama Grafiti.

Darmuki, Hariyadi, dan Hidayati. 2020. "Peningkatan Minat dan Hasil Belajar Keterampilan Berbicara Menggunakan Metode Mind Map pada Mahasiswa Kelas IA PBSI IKIP PGRI Bojonegoro Tahun Akademik 2019/2020.” Jurnal Kredo 3(2): 263-76.

Ghazali, Syukur. 2013. Pembelajaran Keterampilan Berbahasa Dengan Pendidikan Komunikatif-Interaktif. Bandung: PT Refik.

Gough, A. \& Gough, N. 1969. Environmental Education in Kridel, Craig (Ed.), The SAGE Encyclopedia of Curriculum Studies. New York: Sage Publication.

Hamalik, Oemar. 2005. Metoda Belajar Dan Kesulitan-Kesulitan Belajar. Bandung: Tarsito.

Heru Kurniawan dan Sutardi. 2012. Penulisan Sastra Kreatif. Yogyakarta: Graha Ilmu. Iru, La dan Arihi, La Ode Safiun. 2012. Pendekatan, Metode, Strategi, Dan ModelModel Pembelajaran. Yogyakarta: Multi Presindo.

Ismail. 2016. "Diagnosis Kesulitan Belajar Siswa Dalam Pembelajaran Aktif Di Sekolah.” Jurnal Edukasi 2(1): 30-43.

Komaidi, Didik. 2007. Aku Bisa Menulis. Yogyakarta: Sabda Media.

Lestari, Riska Fita. 2019. "Kohesi dan Koherensi Paragraf dalam Karangan Narasi Mahasiswa Teknik Angkatan 2017 Universitas PGRI Banyuwangi.” Jurnal Kredo

126 | Jurnal Kredo

Vol. 4 No. 1 Oktober 2020 


Kredo 4 (2020)
KREDO: Jurnal Ilmiah Bahasa dan Sastra
Terakreditasi Sinta 4 berdasarkan Keputusan Direktorat
Jenderal Penguatan Riset dan Pengembangan,
Kementerian Riset, Teknologi dan Pendidikan Tinggi
Republik Indonesia
Nomor: 23/E/KPT/2019. 08 Agustus 2019
https://jurnal.umk.ac.id/index.php/kredo/index

3(1): 73-82.

Partowisastro, K. 1986. Diagnosa Dan Pemecahan Kesulitan Belajar 1. Jakarta: Erlangga.

Purwanto. 2013. Evaluasi Hasil Belajar. Yogyakarta: Pustaka Pelajar.

Ristiyani, E., \& Bahriah, E. S. 2016. "Analisis Kesulitan Belajar Kimia Siswa Di SMAN X Kota Tangerang Selatan." Jurnal Penelitian dan Pembelajaran IPA (JPPI) 2(1): 18-29.

Sambodja, Asep. 2007. Cara Mudah Menulis Fiksi. Jakarta: Bukupop.

Slameto. 2010. Belajar Dan Faktor-Faktor Yang Mempengaruhi. Jakarta: Rineka Cipta.

Sobari, T. 2015. "Penerapan Teknik Siklus Belajar Dalam Pembelajaran Menulis Laporan Ilmiah Berbasis Vokasional Di Smk.” Jurnal Semantik STKIP Siliwangi 1(1): 17-41. https://doi.org/10.22460/semantik.1.1.

Sofia, Fathurohman, dan Purbasari. 2020. "Penerapan Model Contextual Teaching and Learning Terhadap Peningkatkan Keterampilan Menulis Pendapat Pribadi.” Jurnal Kredo 3(2): 249-62.

Suparno. 2011. Bagaimana Menulis Lintas Kurikulum. Bandung: Citra Aditya Bakti. Suryani, Y.E. 2010. "Kesulitan Belajar.” Magistra (73).

Syah, Muhibbin. 2007. Psikologi Belajar. Jakarta: PT. Raja Grafindo Persada.

Syawqi, Ahmad. 2017. "Mentradisikan Menulis Bagi Pustakawan.” Media Pustakawan 24(1). https://ejournal.perpusnas.go.id/mp/article/download/167/160.

Tarigan, \& Henry, G. 1994. Menulis Sebagai Suatu Keterampilan Berbahasa. Bandung: Angkasa.

Usep Pahing Sumantri. 2004. "Motivasi Pustakawan Dalam Menulis Karya Ilmiah, Yang Dipublikasikan (Survei Di Pusat Perpustakaan Dan Penyebaran Teknologi Pertanian).” Jurnal Perpustakaan Pertanian 13(2).

Wahab, Aziz. 2008. Penilaian Hasil Proses Belajar Mengajar. Bandung: PT. Remaja Rosdakarya.

Warno. 2009. "Pengaruh Keterampilan Penalaran Terhadap Keterampilan Menulis Ditinjau Dari Status Sosial Ekonomi Orang Tua (Studi Ex Post Facto Di SMP

FAKTOR PENYEBAB KESULITAN MENULIS FABEL DAN MODEL PEMBELAJARAN | 127 YANG DIHARAPKAN MAHASISWA PENDIDIKAN BAHASA DAN SASTRA INDONESIA 


Kredo 4 (2020)
KREDO: Jurnal Ilmiah Bahasa dan Sastra
Terakreditasi Sinta 4 berdasarkan Keputusan Direktorat
Jenderal Penguatan Riset dan Pengembangan,
Kementerian Riset, Teknologi dan Pendidikan Tinggi
Republik Indonesia
Nomor: 23/E/KPT/2019. 08 Agustus 2019
https://jurnal.umk.ac.id/index.php/kredo/index

Negeri 1 Dan 2 Slogohimo).” Universitas Sebelas Maret. http://eprints.uns.ac.id/7640/1/105181510200907141.pdf.

Wengkang, Thelma I. M. 2016. "Pembelajaran Berbasis Lingkungan Dalam Teks Genre Sastra." In Proceeding International Conference on Literature XXV, , 737.

Wiedarti, Pangesti. 2005. Menuju Budaya Menulis. Yogyakarta: Tiara Wacana.

Yahya, Andayani, dan Saddhono. 2018. "Hubungan Penguasaan Kosakata dengan Kesalahan Diksi dalam Kalimat Bahasa Indonesia Mahasiswa BIPA Level Akademik.” Jurnal Kredo 1(2): 53-70.

Yusuf, Pawit M. 2013. "Dasar-Dasar Penulisan Paper: Teknik Cepat Menulis Karya Ilmiah.” In Kursus Pelatihan Instruktur Literasi Informasi Paket A,.

Zubaidah, Siti. 2017. "Keterampilan Abad Ke-21: Keterampilan Yang Diajarkan Melalui Pembelajaran." https://www.researchgate.net/publication/318013627_keterampilan_abad_ke21_keterampilan_yang_diajarkan_melalui_pembelajaran. 